\title{
Changes in pathogenic characters of Pseudomonas tolaasii 6264 strain by storage period
}

\author{
Yeong-Bae Yun ${ }^{1}$ (D) $\cdot$ Jeong-Hun Huh ${ }^{1}$ (D) Young-Kee Kim $^{1}$ (D) \\ 저장 기간에 따른 Pseudomonas tolaasii 6264 균주의 병원 특성 변화
}

윤영배 ${ }^{1} \cdot$ 허정훈 $^{1} \cdot$ 김영기 $^{1}$

Received: 30 October 2018 / Accepted: 14 November 2018 / Published Online: 31 December 2018

(C) The Korean Society for Applied Biological Chemistry 2018

\begin{abstract}
Pseudomonas tolaasii strain No. 6264 has been isolated from mushroom tissue and identified as one of the major pathogen causing brown blotch disease. It secretes peptide toxins, known as tolaasin and its analogue peptides. P. tolaasii 6264 has been used as a typical pathogenic strain to study the brown blotch disease for last 20 years after confirming its blotch-forming ability, hemolytic activity, and white line formation. In this study, the characteristics of $P$. tolaasii 6264 strain were analyzed and compared according to storage period. Strains of P. tolaasii 6264 stored annually since 2012 were cultured and their pathogenic characters were analyzed. When the $16 \mathrm{~S}$ rRNA sequences were compared, all strains were divided into two groups. Pathogenic characters including hemolytic activity, blotch-forming ability, and white line test were also investigated. The strains, $P$. tolaasii 6264-15-2 and $P$. tolaasii 6264-17, had all three activities; however, the rest of stored strains showed only blotch-forming ability losing other pathogenic characters. Tolaasin peptides were purified from the bacterial cultures and analyzed by mass spectrometry. The strains, $P$. tolaasii $6264-15-2$ and $P$. tolaasii 6264-17, secreted Tol I (1987 Da), Tol II (1943 Da), and its analogues (1973 Da, $2005 \mathrm{Da}$ ) while some of these peptides were not found in the media cultured other strains. These results
\end{abstract}

Young-Kee Kim $(\bowtie)$

E-mail:ykkim10@cbnu.ac.kr

${ }^{1}$ Department of Environmental and Biological Chemistry, Chungbuk National University, Cheongju, Chungbuk 28644, Republic of Korea

This is an Open Access article distributed under the terms of the Creative Commons Attribution Non-Commercial License (http://creativecommons. org/licenses/by-nc/3.0/) which permits unrestricted non-commercial use, distribution, and reproduction in any medium, provided the original work is properly cited. indicate that the pathogenicity of $P$. tolaasii could be varied during the storage period.

Keywords Brown blotch disease $\cdot$ Mass spectroscopy $\cdot$ Peptide composition $\cdot$ Storage period $\cdot$ Tolaasin

\section{서 론}

버섯은 비타민 $\mathrm{B}$ 와 $\mathrm{D}$, 항산화 물질, 불포화지방산 등을 다양하 게 함유하고 있으며[1-3], 최근 연구에서는 신선한 버섯을 매일 섭취한 여성은 유방암 발병이 $64 \%$ 까지 감소한다고 보고하였다 [4]. 버섯의 다양한 효능에도 불구하고 매년 버섯 생산 면적은 감소하고 있으며, 이의 주된 이유는 세균성갈반병의 빈번한 발 생이 버섯 생산에 큰 피해를 주기 때문이다. 버섯에 병을 일으 키는 많은 세균들 중 Pseudomonas tolaasii는 펩티드 독소인 tolaasin을 분비하여 버섯 세포를 파괴하며 조직을 괴사시켜 갈 반병을 일으킨다. 갈반병은 버섯 갓 표면에 갈색 무늬를 형성 하며 부패시켜 버섯 품질의 저하로 판매는 물론 재배사의 완벽 한 소독 과정을 거치지 않으면 후속 재배를 불가능하게 만든다 . 갈반병이 발병하면 재배 농가의 다른 재배사 및 재배 단지 전 체로 빠르게 확산될 수 있어 버섯 재배의 기피는 물론 전체 버 섯 생산 면적 감소의 주요 원인이 되고 있다[5].

Tolaasin은 P. tolaasii에 의해 생성되는 18 개의 아미노산과 지 방산으로 이루어진 lipodepsipeptide로, 분자 내에 친수성 부위 와 소수성 부위를 모두 갖고 있어 양친매성(amphipathic) 펩티 드 독소이다[6]. 이 독소는 세포막에 결합한 후 다중화결합을 통해 pore를 형성하며 삼투압 교란으로 버섯 세포의 파괴를 유 발한다[7]. Tolaasin에 의한 발병은 alamethicin, cecropin A, ovispirin 등 다른 pore-forming peptide의 작용 기작과 유사하다 
[8-10]. Nutkins 등[11]은 tolaasin의 1차 구조를 처음 결정하였 으며, $1985 \mathrm{Da}$ 의 Tolaasin I (Tol I)과 $1943 \mathrm{Da}$ 의 Tolaasin II (Tol II)를 보고하였다. Cho 등[12]은 국내에서 분리한 병원균인 P. tolaasii 6264가 2가지의 tolaasin 유사체인 Tol I 및 Tol II 를 합성하는 것을 확인하였다.

본 연구에서는, 지난 20 년간 대표적인 갈반병 원인균으로 사 용해온 P. tolaasii 6264에 대하여 저장 기간에 따른 균주의 병 원성과 균주가 분비하는 독성 펩티드의 조성 변화를 조사하였 다. 균주는 $20 \%$ 의 glycerol을 함유한 신선한 PAF 배지에 지난 6년간 매년 보관하였으며, 배양하여 생존한 균주에 대하여 다양 한 병원성을 확인하고, 저장기간 중 병원 특성 변이 여부를 조 사하였다.

\section{재료 및 방법}

\section{Tolaasin의 분리}

P. tolaasii 6264 균주를 Pseudomonas agar F (PAF; $\mathrm{MgSO}_{4}$ $1.5 \mathrm{~g}, \mathrm{~K}_{2} \mathrm{HPO}_{4} 1.5 \mathrm{~g}$, Bacto-Peptone $10 \mathrm{~g}$, Bacto-Tryptone $10 \mathrm{~g}$, Glycerol $10 \mathrm{~mL}$ per liter) 액체 배지에 접종하여 배양한 후, 균 체가 제거된 배양액에 $30 \%$ 의 ammonium sulfate를 가하고 4 ${ }^{\circ} \mathrm{C}$ 에서 정치한 후 초원심분리하여 crude tolaasin을 얻었고, 이 를 순수분리에 사용하였다[12]. Tolaasin의 순수분리는 Cho 등 [12]의 방법에 따라 수행하였으며, gel permeation chromatography 와 $\mathrm{HPLC}$ 로 분석하였다.

\section{버섯조직함몰검정법(Pitting test), 용혈활성 측정, 흰색침강선형 성시험(White line test)}

양송이버섯을 이용하여 각 시기별 P. tolaasii 6264 균주의 갈반형 성능을 확인하였다. 먼저 양송이버섯의 자실체를 수평으로 절단 한 면에 균주배양액을 $5 \mu \mathrm{L}$ 점적하여 흡수시킨 후, 수분이 유지 되도록 장치한 square dish에 담아 밀봉하였다. $25^{\circ} \mathrm{C}$ 에서 12-24시 간 동안 배양하면서 점적부위의 변색 및 함몰 정도를 관찰하였다.

각 시기별 P. tolaasii 6264 균주의 세포독성을 측정하기 위 하여 쥐의 적혈구를 이용하였다. 용혈활성 측정에 사용한 적혈 구는 사용 직전에 HEPES-buffered saline (HBS; $150 \mathrm{mM}$ $\mathrm{NaCl}, 5 \mathrm{mM} \mathrm{KCl}, 5 \mathrm{mM}$ HEPES, $1 \mathrm{mM} \mathrm{MgSO}, \mathrm{pH} 7.4)$ 용액으로 10 배 희석하였고, 이것을 최종 반응 용액에 $10 \%$ 가 되 도록 처리하였다. 용혈활성 측정시 $37^{\circ} \mathrm{C}$ 에서 $1 \%$ 의 적혈구를 30 분 이내에 모두 용혈시키는 tolaasin의 농도를 1 hemolytic unit로 정하여 사용하였다. 용혈활성은 UV/vis spectrophotometer (U-2000, Hitachi, Tokyo, Japan)를 사용하여 $600 \mathrm{~nm}$ 에서 흡광 도 변화로 측정하였다.

흰색침강선형성시험(White line test)은 Pseudomonas reactans ATCC 51314 균주 배양액을 PAF 고체 배지 중간에 일직선으 로 접종한 후, 시기별 P. tolaasii 6264 균주 배양액 $1 \mu \mathrm{L}$ 를 $P$. reactans ATCC 51314 균주와 약 $5 \mathrm{~mm}$ 의 간격을 두고 점적한 다. 접종을 완료한 agar plate는 $25^{\circ} \mathrm{C}$ 에서 24-48시간 동안 배양 하며, 두 균주 사이에 흰색 침전 형성 여부를 확인하였다.

\section{Tolaasin 및 유사체의 HPLC 분석 및 분자량 분석}

Gel permeation chromatography로부터 얻은 각 균주들의 분획들
은 HPLC 및 질량분석기로 분석하였다. 순수분리한 tolaasin 및 유사체는 질량분석기의 양이온모드로의 원활한 측정을 위해 ziptip (Millipore ziptips, Sigma-Aldrich, St. Louis, MO, USA)을 이용 하여 농축액의 염을 제거하였다. Matrix는 $50 \% \mathrm{ACN} / 0.1 \%$ TFA $1 \mathrm{~mL}$ 에 $7 \mathrm{mg}$ a-cyano-4-hydroxycinnamic acid를 용해시켜 준비 하였다. 측정 직전에 desalted sample을 matrix와 $1 \mu \mathrm{L}$ 씩 취하여 혼합한 후, 이 혼합액을 stainless steel target plate (384-well plate, Shimadzu, Tokyo, Japan)에 점적한 후 건조시켰다. Tolaasin의 분 자량 측정은 MALDI-TOF mass spectrometer (ultrafleXtremeIII, Bruker Daltonics, Bremen, Germany)를 이용하였다. Mass spectrum은 $20 \mathrm{kV}$ 의 가속 전압으로 양이온 모드에서 기록되었으 며, laser로 500번 찍은 후 평균치로 나타내었다. Tolaasin의 분 자량을 측정하기 전, external calibration은 bradykinin, angiotensin, bombesin, renin, somatostatin 등의 다양한 standard peptide로 구 성된 peptide mixture로 수행하였다.

\section{결 과}

\section{시기별 저장된 P. tolaasii 6264 균주의 유전적 확인}

본 연구실에서는 갈반병 또는 이와 유사한 병증을 보인 버섯으 로부터 다양한 균주를 분리하였으며[13,14], 분리한 균주들의 병 원성을 비교하기 위하여 P. tolaasii 6264 균주를 대조균주로 사 용해 왔다. 따라서 P. tolaasii 6264 균주의 병원 특성은 잘 유 지되어야 하나, 균주의 장기보관 중 일부 병원 특성의 변화를 확인하였기에 보관중인 P. tolaasii 6264 균주들의 특성을 조사 하였다. 본 연구에서는 $-80{ }^{\circ} \mathrm{C}$ 의 초저온냉동고에 보관해오던 균 주들 중 2012년부터 2017년까지 저장기간이 서로 다른 $P$. tolaasii 6264 균주의 다양한 특성을 비교하였다. 선발한 균주는 총 6 종으로, 2012년(6264-12), 2013년(6264-13), 2015년(626415-1, 6264-15-2), 2016년(6264-16), 2017년(6264-17)에 냉동 보관한 균주였고, 균주번호에 연도를 붙여 구분하였다. 2014년 (6264-14)에도 보관한 균주가 있었으나, 배양하였을 때 colony 형성이 이루어지지 않아 실험대상에서 제외하였다. 이들이 $P$. tolaasii 6264 균주임을 확인하기 위하여, 균주의 $16 \mathrm{~S}$ rRNA 염 기서열로 계통수 분석을 수행하였다(Fig. 1). 각 균주들의 염기 서열을 분석한 결과, P. tolaasii ATCC 33618 균주와의 상동성 이 가장 높았다. 계통수상에서 이들 균주는 두 그룹으로 나뉘 었으며, P. tolaasii 6264-12, P. tolaasii 6264-15-2, P. tolaasii 6264-17 균주는 P. tolaasii ATCC 33618 균주와 가장 근접하 게 위치하였고, 이 때 균주와의 상동성은 각각 $99.59,99.52$, 99.85\%이었다. 반면, P. tolaasii 6264-13, P. tolaasii 6264-151, P. tolaasii 6264-16 균주는 계통수상에서 근소한 차이를 보 였으며, P. tolaasii ATCC 33618 균주와의 상동성은 각각 $99.45,99.31,99.16 \%$ 이었다. 이 균주들의 염기서열은 $\mathrm{Kim}$ 과 Chun[15]에 의해 보고된 종 분화 임계점인 $98.6 \%$ 이상의 값을 가졌고, P. tolaasii ATCC 33618 균주의 염기서열과 99\% 이상 의 상동성을 가져 모두 P. tolaasii 6264 균주에서 유래된 균주 임을 확인하였다.

저장된 P. tolaasii 6264 균주들의 병원 특성

저장기간이 서로 다른 P. tolaasii 6264 균주들의 독소 분비 및 


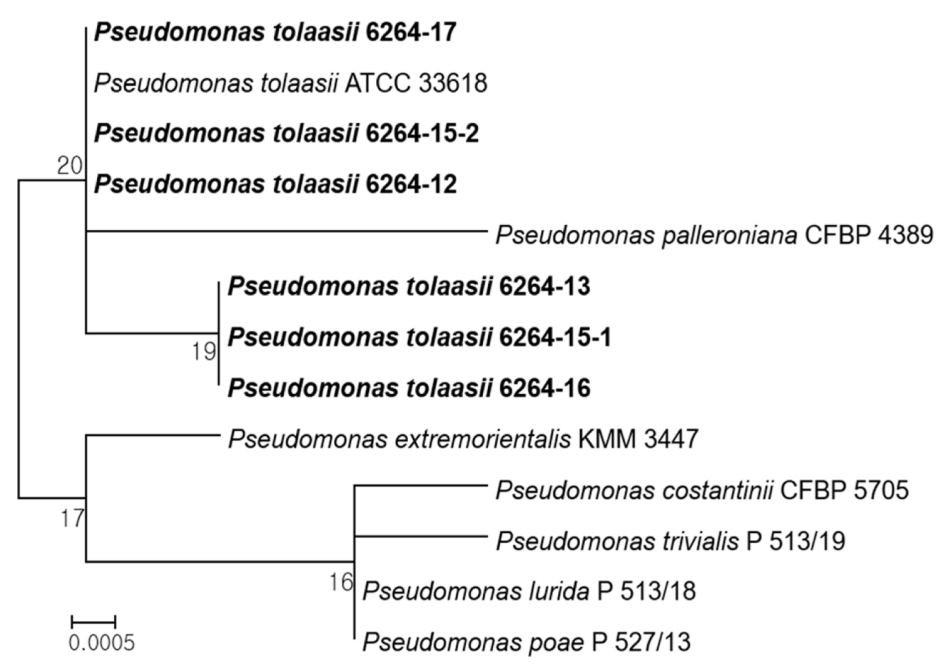

Fig. 1 Phylogenetic analysis of 16S rRNA genes obtained from P. tolaasii 6264 strains stored for different periods. The number after 6264 represent the year stored
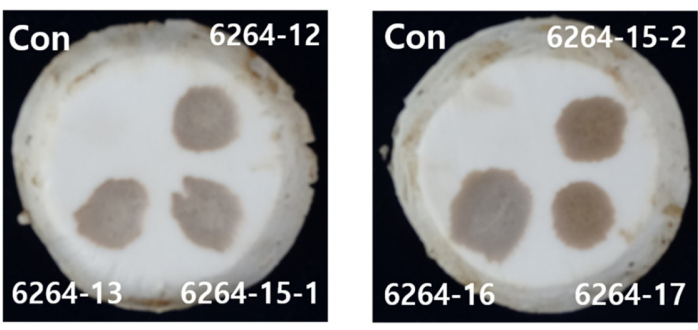

Fig. 2 Blotch formations in pitting tests by the culture supernatants of $P$. tolaasii 6264 strains stored

세포 독성을 비교하기 위하여 세 가지 병원성 확인법인 버섯조 직함몰검정법(pitting test)과 용혈활성검정법(hemolysis), 흰색침 강선형성시험(white line test)을 수행하였다. 먼저, 버섯조직함몰 검정법은 실제 버섯에서 균주의 병원성을 확인하는 방법으로, 서로 다른 저장 기간의 P. tolaasii 6264 균주들 모두 동일하게 갈반을 형성하였다(Fig. 2).

P. tolaasii 균주가 분비하는 펩티드 독소에 의해 나타나는 용 혈활성은 펩티드의 독성에 따라 용혈 시간이나 용혈 정도에서 차이를 보이므로, 적혈구에 대한 균주들의 세포 독성을 직접적 으로 비교할 수 있는 방법이다. P. tolaasii 6264-15-2와 $P$. tolaasii 6264-17 균주는 30분 이내에 용혈이 완료된 반면, $P$. tolaasii 6264-12, P. tolaasii 6264-13, P. tolaasii 6264-15-1, P. tolaasii 6264-16 균주는 2시간 동안 용혈활성 변화를 보이지 않았다(Fig. 3).

P. tolaasii 가 분비하는 tolaasin은 P. reactans 가 분비하는 물 질인 White line-inducing principle (WLIP)과 반응하여 침전을 형성한다[16]. 따라서 시기별 P. tolaasii 균주와 P. reactans 균 주를 대치배양하여 흰색침강선 형성 여부를 확인하였다. 용혈활 성의 결과와 같이, P. tolaasii 6264-15-2와 P. tolaasii 6264-17 균주는 흰색침강선이 뚜렷하게 형성된 것을 볼 수 있었으나, 그 외 균주들은 위 두 균주와 비교하여 매우 희미하게 나타났다 (Fig. 4). 이러한 결과는 P. tolaasii 6264-15-2와 P. tolaasii 6264-17 균주를 제외한 다른 균주들은 원래 P. tolaasii 6264

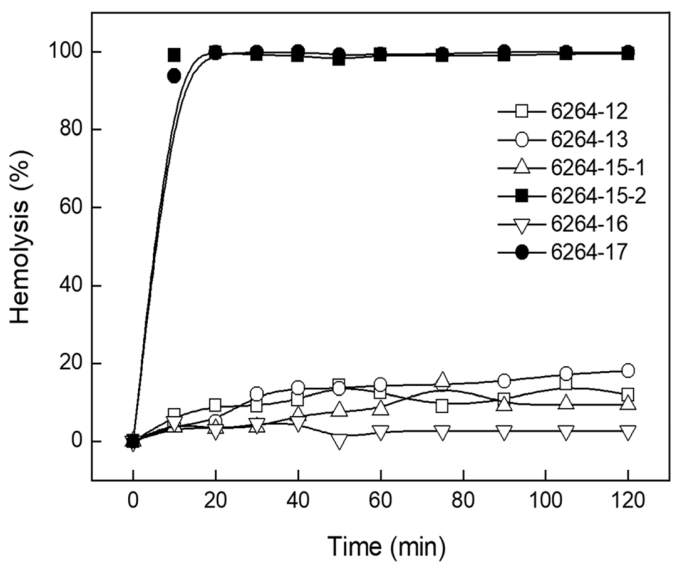

Fig. 3 Hemolytic activities of the strains of $P$. tolaasii 6264 stored for different periods

균주에 비하여 저장기간 동안 tolaasin 생성능이 약해지거나 퇴 화되었음을 의미한다.

\section{시기별 P. tolaasii 6264 균주들의 펩티드 조성}

Tolaasin의 순수 분리를 위하여 균주배양액에 $\left(\mathrm{NH}_{4}\right)_{2} \mathrm{SO}_{4}$ 를 처리 하여 tolaasin을 포함한 펩티드를 농축하고, 이것을 gel permeation chromatography를 통하여 분획을 얻었다. 각 분획은 $220 \mathrm{~nm}$ 에 서 흡광도를 측정하여 단백질 함량을 확인하였으며, 용혈활성을 측정하여 tolaasin의 포함여부를 결정하였다. P. tolaasii 626415-2 균주는 15번부터 21번 분획에서, P. tolaasii 6264-17 균주 는 15 번부터 20 번 분획에서 용혈활성이 나타났고, 그 외 다른 균주들은 용혈활성을 가진 분획이 없었다(Fig. 5). 각 균주에서 얻은 분획들의 펩티드 함유 여부 분석은 $\mathrm{HPLC}$ 를 이용하여 이 루어졌다. 용혈활성을 가진 P. tolaasii 6264-15-2와 P. tolaasii 6264-17 균주를 포함하여, 용혈활성이 없는 모든 균주들에서 15 번부터 20 번의 분획을 분석하였다. HPLC 분석에서 모든 균주 들의 분획은 약 10.5 분의 retention time에서 peak를 가졌으나, P. tolaasii 6264-15-2와 P. tolaasii 6264-17 균주의 chromatogram 


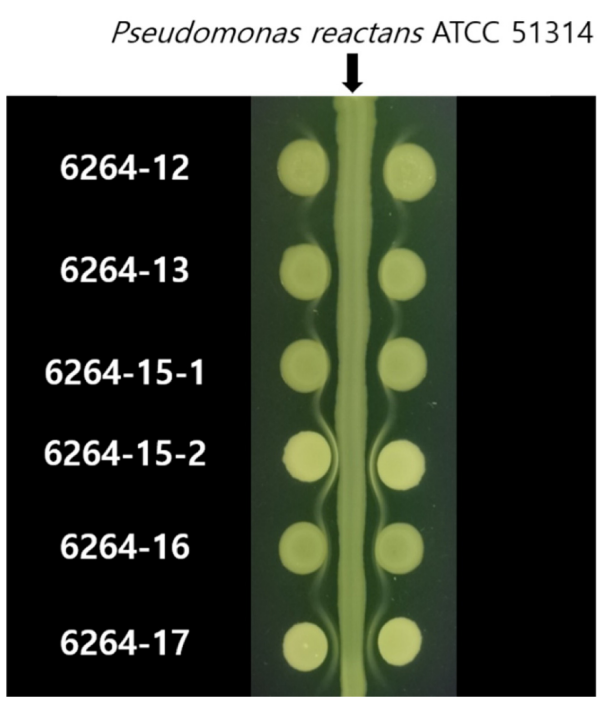

Fig. 4 White line test of $P$. tolaasii 6264 strains. White line formations against $P$. reactans ATCC 51314 were measured

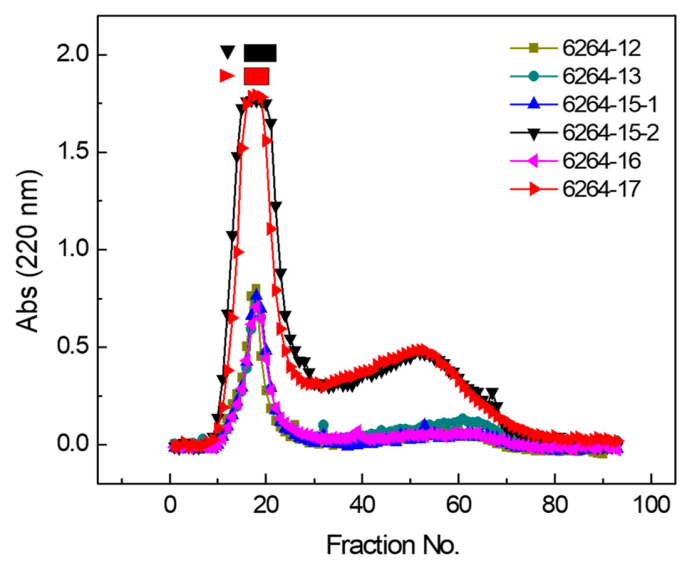

Fig. 5 Gel permeation chromatography of culture extracts of $P$. tolaasii 6264 strains stored for different periods. Fractions containing hemolytic activity were marked by horizontal bar with symbols on the top of the chromatogram

에서는 높은 height와 넓은 면적을 보인 반면, 그 외 다른 균주 들의 peak는 매우 작게 나타났다(Fig. 6).

균주들의 분획에서 관측된 펩티드의 분자량을 MALDI-TOF mass spectrometry를 이용하여 분석하였다. P. tolaasii 6264-16 균주와 P. tolaasii 6264-17 균주의 분획에서 분리한 펩티드 조 성을 분석한 결과, $1900 \mathrm{Da}$ 과 $2100 \mathrm{Da}$ 사이에서 tolaasin 및 유사체들을 확인하였다(Fig. 7). P. tolaasii 6264-16 균주에서 측정한 peak는 $\mathrm{m} / \mathrm{z} 1988.4(\mathrm{M}+\mathrm{H})^{+}$이었으며(Fig. 7A), $P$. tolaasii 6264-17 균주에서 측정한 분자들의 peak는 m/z 1944. $4(\mathrm{M}+\mathrm{H})^{+}, 1974.1(\mathrm{M}+\mathrm{H})^{+}, 1988.4(\mathrm{M}+\mathrm{H})^{+}, 2006.5(\mathrm{M}+\mathrm{H})^{+}$, $2050.4(\mathrm{M}+\mathrm{H})^{+}$등으로 나타났다(Fig. 7B). 측정한 peak 값은 양이온 모드에서 측정되어 $\mathrm{H}^{+}$이 분자와 결합되어 있는 형태이 므로, 실제 분자량은 $1943.4 \mathrm{Da}$ (Tol II), $1973.1 \mathrm{Da}, 1987.4$ $\mathrm{Da}$ (Tol I), 2005.5 Da, 2049.4 Da임을 알 수 있다. Table 1 에는 각 시기별 P. tolaasii 6264에서 측정된 분자량 값들을 정

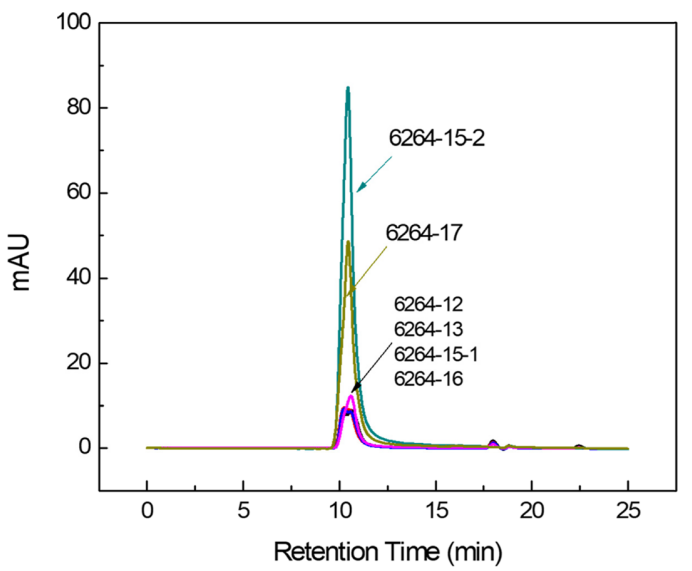

Fig. 6 HPLC analysis of culture extracts of $P$. tolaasii 6264 strains stored for different periods
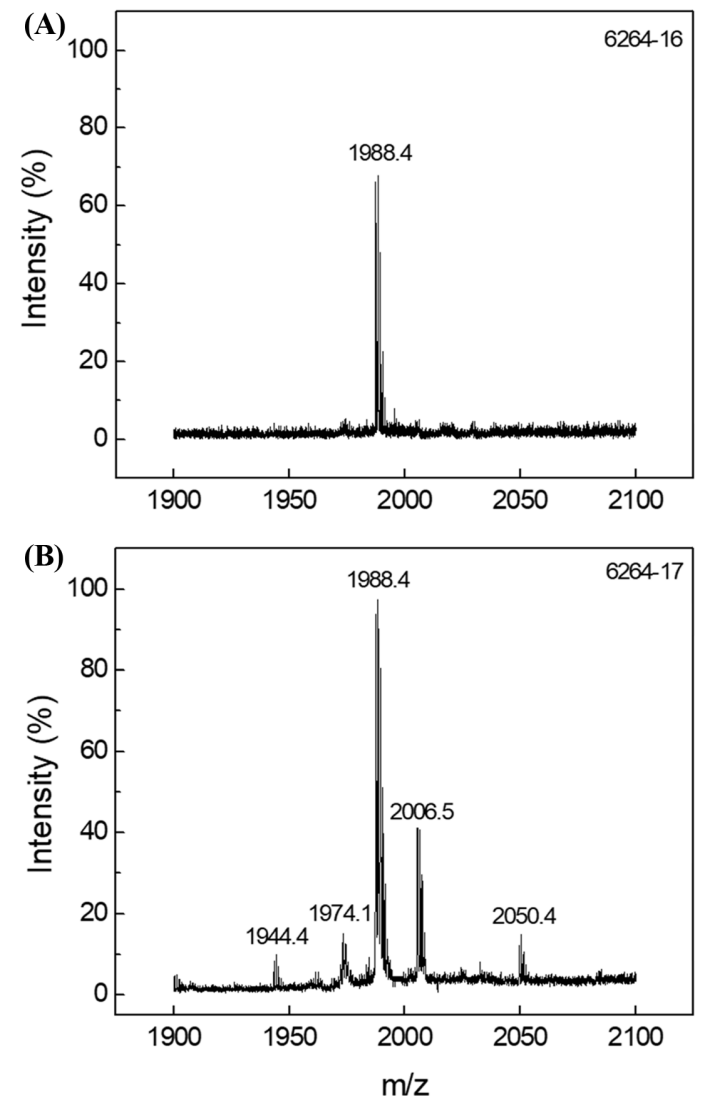

Fig. 7 Mass spectrum of tolaasin and its analogue peptides purified from the culture extracts. (A) P. tolaasii 6264-16, (B) P. tolaasii 6264-17

리하였다. 용혈활성과 갈반형성능, 흰색침강선형성능을 모두 보 였던 P. tolaasii 6264-15-2와 P. tolaasii 6264-17 균주의 분획 에서는 Tol I (1987 Da), Tol II (1943 Da), 1973 Da, 2005 $\mathrm{Da}$ 등의 tolaasin 유사체가 관측되었다. 반면, 갈반형성능만 있 었던 그 외 균주들의 분획에서는 Tol I 및 $2005 \mathrm{Da}$ 의 유사체 만 확인되었으며, P. tolaasii 6264-15-1의 분획에서는 tolaasin 또는 유사체가 전혀 관측되지 않았다. 
Table 1 Molecular weights of tolaasin and its analogues secreted by the strains of $P$. tolaasii 6264 stored for different periods

\begin{tabular}{lccccc}
\hline \multicolumn{5}{c}{ Molecular weights (Da) } \\
\hline Strain No. & Tol II & $\begin{array}{c}* \text { S-2 } \\
* * \text { B-B }\end{array}$ & Tol I & $\begin{array}{c}\text { S-3 } \\
\text { B-C }\end{array}$ & unknown \\
\hline $6264-12$ & & & 1987.3 & 2005.3 & \\
$6264-13$ & & & 1987.3 & 2005.3 & \\
$6264-15-1$ & & & & & \\
$6264-15-2$ & 1943.1 & 1973.1 & 1987.2 & 2005.4 & TR*** \\
$6264-16$ & & & 1987.4 & & \\
$6264-17$ & 1943.4 & 1973.1 & 1987.4 & 2005.5 & 2049.4 \\
\hline
\end{tabular}

*S-2: No. 2 peptide, S-3: No. 3 peptide isolated by Shirata et al. [18] **B-B and B-C: B and C peptides isolated by Bassarello et al. [19] $* * *$ TR: Trace

\section{고 찰}

계통수 분석을 통해 균주들의 $16 \mathrm{~S}$ rRNA 유전자 염기서열을 비 교하였을 때, 2012년부터 2017년까지 저장된 6 균주 모두 $P$. tolaasii ATCC 33618 균주와 99\% 이상의 상동성을 보였다. 또 한, P. tolaasii 6264를 숙주균으로 하는 박테리오파지(\$6264)를 각 균주에 처리하였을 때, 6 균주 모두가 파지에 의해 사멸되 어 모두 P. tolaasii 6264 균주임을 확인하였다(자료 미제시). Yun 등[13]은 병징이 나타난 버섯에서 얻은 다양한 P. tolaasii 균주들을 $16 \mathrm{~S} \mathrm{rRNA}$ 유전자 분석과 용혈활성 분석을 통하여 $P$. tolaasii $\mathrm{P} 1 \alpha$ 와 P. tolaasii $\mathrm{P} 1 \beta$ 균주로 분류하였다. 본 연구에서 사용한 P. tolaasii 6264 균주들은 $\mathrm{P} 1 \alpha$ 에 속하는 균주임에도 $\mathrm{P} 1 \alpha$ 와 $\mathrm{P} 1 \beta$ 균주로 분류되었다. 계통수상에서는 P. tolaasii 6264-12, P. tolaasii 6264-15-2, P. tolaasii 6264-17 균주가 $\mathrm{P} 1 \alpha$ 에 속하였으며, P. tolaasii 6264-13, P. tolaasii 6264-15-1, P. tolaasii 6264-16 균주들은 $\mathrm{P} 1 \beta$ 에 속하였다. 각 균주의 병원 성을 비교해 보면, P. tolaasii 6264-15-2와 P. tolaasii 6264-17 균주는 갈반형성능과 용혈활성, 흰색침강선형성능을 모두 갖고 있어 $\mathrm{P} 1 \alpha$ 균주의 특성과 같은 반면, P. tolaasii 6264-12 균주 와 나머지 균주는 모두 갈반형성능만 보여 $\mathrm{P} 1 \beta$ 균주의 특성과 같다. 이러한 결과로 보아, 균주의 $16 \mathrm{~S} \mathrm{rRNA}$ 염기서열 분석에 따른 분류는 병원성 분석에 따른 분류와 $100 \%$ 일치하지는 않 는 것으로 판단된다. Burlinson 등[17]도 뉴질랜드 버섯재배사에 서 분리한 Pseudomonas 속의 균주가 갈반형성능도 있고 WLIP 와 흰색침강선도 형성하지만, P. tolaasii 균주와는 다른 염기서 열 및 계통수를 보였다고 보고하였다.

세 가지 병원성에서 모두 양성을 보인 P. tolaasii 6264-15-2와 P. tolaasii 6264-17 균주는 Tol I (1987 Da), Tol II (1943 $\mathrm{Da}$, $1973 \mathrm{Da}, 2005 \mathrm{Da}$ 등의 tolaasin 유사체(analogue)를 분 비하는 것으로 확인되었다. Shirata 등[18]은 P. tolaasii Paine 균주로부터 8 개의 tolaasin 유사체를 분리하였으며, 구조적으로 4번과 6번 유사체가 각각 Tol I 및 Tol II와 같았다. 또한, Bassarello 등[19]도 P. tolaasii NCPPB2192 균주에서 7개의 tolaasin 유사체를 분리하였고, 그 중 두 유사체는 Tol I과 Tol II이었다. 본 논문에서 P. tolaasii 6264-15-2와 P. tolaasii 6264-17 균주에서 확인한 $1973 \mathrm{Da}$ 과 $2005 \mathrm{Da}$ 의 유사체는 각 각 Shirata 등의 연구에서 2 번과 3 번, Bassarello 등의 연구에서 $\mathrm{B}$ 와 $\mathrm{C}$ 와 같았다(Table 1). 이는 본 연구에서 병원성을 보인 $P$. tolaasii 6264-15-2와 P. tolaasii 6264-17 균주가 분비하는 펩티 드의 조성이 이전 연구에서의 결과와 유사함을 뜻한다. 다만, 갈반형성능만 보인 그 외 균주에서는 Tol I (1987 Da)과 2005 $\mathrm{Da}$ 의 유사체만 확인되거나 tolaasin 유사체가 확인되지 않았음 에도 불구하고 버섯에 갈반을 형성하였다(Fig. 2). 이러한 결과 는 이전 연구에서 tolaasin이 pore를 형성하여 버섯 세포를 괴 사시킨다는 결과와 다르게 갈반병 발생에 tolaasin 이외의 다른 인자가 관여할 수 있을 가능성을 제시한다.

P. tolaasii 6264 균주는 매년 저장 보관 전에 갈반형성능, 용 혈활성, 흰색침강선형성능 등의 병원성 활력을 측정하여 모두 양성임을 확인하였다. 따라서, 병원 특성을 가졌던 균주를 저장 하였음에도 용혈 활성이 없는 균주들은 저장 기간 중 변이를 일으킨 것으로 확인된다. 저장 기간이 서로 다른 P. tolaasii 6264 균주에서 나타난 병원성의 차이는 여러가지의 요인으로 볼 수 있다. 일반적으로, 미생물이 서식하기에 양분 조건이 열 악한 조건에서는 충분한 양분 조건에서보다 병원성이 증가할 수 있으나[20], 저장 시에 같은 $20 \%$ glycerol을 함유한 PAF 배지 를 사용하였기 때문에 양분 조건의 차이는 없을 것이다. 또한, 균주의 병원성은 일정 수준 이상의 미생물 농도에서 병원성을 조절하는 자가유도물질(autoinducer)에 의해 일어나는 현상인 quorum sensing에 따라 달라질 수 있으며[21], 미생물의 병원성 에 관여하는 유전자의 변화에 따라 균주의 병원성이 변할 수 있다[22]. Kim의 연구[23]는 tolaasin 합성과 관련된 여러가지 유전자 및 효소를 밝혔으며, 그 중 $\mathrm{ABC}$ (ATP-binding cassette) transporter permease가 tolaasin의 합성 및 수송에 관여한다고 보고하였다. Tolaasin은 세포 외부로 분비되는 2 차 대사산물이 기 때문에 이 수송단백질이 없다면 합성이 되더라도 세포 바깥 으로 분비되지 않아 병원성을 잃을 수 있다. 이에 따라 시기별 로 저장기간이 다른 P. tolaasii 6264 균주에서 나타난 병원성 의 차이는 tolaasin 합성 유전자의 발현에 변화가 일어나 나타 난 결과로 볼 수 있다.

분비되는 펩티드 조성에서 차이가 있음에도 불구하고 버섯에 서 갈반이 형성되는 것은 tolaasin류의 펩티드 이외의 다른 물 질이 갈반형성에 관여할 가능성을 의미한다. 양친매성 펩티드인 tolaasin과 같이 다양한 미생물에 의해 분비되는 biosurfactant (biodetergent)가 세포 독성을 가질 수 있으며[24], 특히 Bacillus subtilis에 의해 생성되는 lipopeptide인 surfactin은 암세포에 대 한 독성이 밝혀져 항암제로 개발 중에 있다[25]. 그 외의 biosurfactant로 밝혀진 iturin, fengycin, digitonin, rhamnolipid 등의 유사한 물질이 버섯 조직에서 갈반을 일으켰을 가능성이 있다. 따라서, 이후 연구에서 분자량 분석을 통해 biosurfactant 물질의 존재여부를 확인하고, 버섯조직함몰검정법을 통해 해당 물질의 갈반 형성 여부를 확인해야할 것이다. 이에 더하여, 이 전 연구에서 P. tolaasii로 분류되었던 $\mathrm{P} 1 \alpha, \mathrm{P} 1 \beta, \mathrm{P} 1 \gamma$ 균주에서 [13] 이들의 병원성과 균주가 분비한 펩티드 조성 변화를 조사 한다면, tolaasin의 세포 독성 기전과 tolaasin 이외의 갈반병에 관여하는 물질에 대해 알 수 있을 것이다.

\section{초 록}

Pseudomonas tolaasii 6264 균주는 버섯 조직에서 분리하였고, 
갈반병을 일으키는 주요 병원균 중 하나로 확인되었다. 이 균 주는 펩티드 독소인 tolaasin과 유사 펩티드를 분비한다. $P$. tolaasii 6264 는 지난 20 여년간 갈반병 연구를 위한 대표균주로 사용되었으며, 이 균주는 갈반형성능, 용혈활성, 흰색침강선형성 능을 확인한 후 사용하였다. 본 연구에서는, 저장 기간에 따라 P. tolaasii 6264 균주의 특성을 비교분석하였다. 2012년 이후 저장된 P. tolaasii 6264 균주를 매년 배양하여 이들 균주의 병 원성을 분석하였다. $16 \mathrm{~S}$ rRNA 염기서열을 비교하였을 때, 모 든 균주들은 두 그룹으로 나뉘어졌다. 용혈활성, 갈반형성능, 흰 색침강선형성능을 포함한 균주의 병원 특성도 조사하였다. $P$. tolaasii 6264-15-2와 P. tolaasii 6264-17 균주는 세 가지 활성 을 모두 가졌으나, 그 외 균주들은 갈반형성능만 보였으며 다 른 병원 특성들은 잃었다. 각 균주 배양액으로부터 tolaasin 펩 티드를 순수분리하였으며, 질량분석기를 이용하여 분석하였다. P. tolaasii 6264-15-2와 P. tolaasii 6264-17 균주는 Tol I $(1987 \mathrm{Da})$, Tol II (1943 Da)을 비롯한 유사체(1973 Da, 2005 $\mathrm{Da}$ 를 분비하였으며, 다른 균주의 배양액에서는 이 펩티드들의 일부가 발견되지 않았다. 이러한 결과는 P. tolaasii의 병원성이 저장기간동안 변할 수 있음을 보여준다.

Keywords 갈반병 - 저장 기간 - 질량 분석 · 톨라신 - 펩티드 조성

감사의 글 이 논문은 2017 년도 정부(교육부)의 재원으로 한국연구재단의 지원을 받아 수행된 기초연구사업임(No. 2017R1D1A3B03032718).

\section{References}

1. Lee GS, Byun HS, Yoon KH, Lee JS, Choi KC, Jeung EB (2009) Dietary calcium and vitamin $\mathrm{D}_{2}$ supplementation with enhanced Lentinula edodes improves osteoporosis-like symptoms and induces duodenal and renal active calcium transport gene expression in mice. Eur J Nutr 48: 75-83

2. Shi YL, James AE, Benzie IFF, Buswell JA (2002) Mushroom-derived preparations in the prevention of $\mathrm{H}_{2} \mathrm{O}_{2}$-induced oxidative damage to cellular DNA. Teretog Carcinog Mutagen 22: 103-111

3. Chen S, Oh SR, Phung S, Hur G, Ye JJ, Kwok SL, Shrode GE, Melury M, Adams LS, Williams D (2006) Anti-aromatase activity of phytochemicals in white button mushrooms (Agaricus bisporus). Cancer Res 66: 12026-12034

4. Zhang M, Huang J, Xie X, Holman J (2009) Dietary intakes of mushrooms and green tea combine to reduce the risk of breast cancer in Chinese women. Int J Cancer 124: 1404-1408

5. Annual Report for Production of Mushroom (2016) Agricultural information and statistics. Ministry of Agricultural and Forestry, Sejong

6. Jourdan F, Lazzaroni S, Méndez BL, Lo Cantore P, de Julio M, Amodeo P, Iacobellis NS, Evidente A, Motta A (2003) A left-handed $\alpha$-helix containing both L- and D-amino acids: the solution structure of the antimicrobial lipodepsipeptide tolaasin. Proteins 52: 534-543

7. Hiep HM, Endo T, Saito M, Chikae M, Kim DK, Yamamura S, Takamura Y, Tamiya E (2008) Label-free detection of melittin binding to a membrane using electrochemical-localized surface plasmon resonance. Anal Chem 80: 1859-1864

8. Bak M, Bywater RP, Hohwy M, Thomsen JK, Adelhorst K, Jakobsen HJ, Sorensen OW, Nielsen NC (2001) Conformation of alamethicin in oriented phospholipid bilayers determined by ${ }^{15} \mathrm{~N}$ solid-state nuclear magnetic resonance. Biophys J 81: 1684-1698

9. Silva T, Claro B, Silva BFB, Vale N, Gomes P, Gomes MS, Funari SS, Teixeira J, Uhríková D, Bastos M (2018) Unravelling a mechanism of action for a cecropin A-melittin hybrid antimicrobial peptide: the induced formation of multilamellar lipid stacks. Langmuir 34: 21582170

10. Yamaguchi S, Huster D, Waring A, Lehrer RI, Kearney W, Tack BF, Hong M (2001) Orientation and dynamic of an antimicrobial peptide in the lipid bilayer by solid-state NMR spectroscopy. Biophys J 81: 22032214

11. Nutkins JC, Mortishire-Smith RJ, Packman LC, Brodey CL, Rainey PB, Johnstone K, Williams DH (1991) Structure determination of tolaasin, an extracellular lipodepsipeptide produced by the mushroom pathogen Pseudomonas tolaasii paine. J Am Chem Soc 113: 2621-2627

12. Cho KH, Kim ST, Kim YK (2007) Purification of a pore-forming peptide toxin, tolaasin, produced by Pseudomonas tolaasii 6264. J Biochem Mol Biol 40: 113-118

13. Yun YB, Park SW, Cha JS, Kim YK (2013) Biological characterization of various strains of Pseudomonas tolaasii that causes brown blotch disease. J Korean Soc Appl Biol Chem 56: 41-45

14. Mu LL, Yun YB, Park SJ, Cha JS, Kim YK (2015) Various pathogenic Pseudomonas strains that cause brown blotch disease in cultivated mushrooms. J Appl Biol Chem 58: 349-354

15. Kim MC, Chun JS (2014) 16S rRNA gene-based identification of bacteria and archaea using the EzTaxon server. In: Goodfellow M (ed) New approaches to prokaryotic systematics, 1st edn. Elsevier, Oxford, pp $61-74$

16. Lo Cantore P, Lazzaroni S, Coraiola M, Dalla Serra M, Cafarchia C, Evidente A, Iacobellis NS (2006) Biological characterization of white line-inducing principle (WLIP) produced by Pseudomonas reactans NCPPB1311. MPMI 19: 1113-1120

17. Burlinson P, Studholme D, Cambray-Young J, Heavens D, Rathjen J, Hodgkin J, Preston GM (2013) Pseudomonas fluorescens NZ17 repels grazing by C. elegans, a natural predator. ISME J 7: 1126-1138

18. Shirata A, Sugaya K, Takasugi M, Monde K (1995) Isolation and biological activity of toxins produced by a Japanese strain of Pseudomonas tolaasii, the pathogen of bacterial rot of cultivated oyster mushroom. Ann Phytopathol Soc Jpn 61: 492-502

19. Bassarello C, Lazzaroni S, Bifulco G, Lo Cantore P, Iacobellis NS, Riccio R, Gomez-Paloma L, Evidente A (2004) Tolaasins A-E, five new lipodepsipeptides produced by Pseudomonas tolaasii. J Nat Prod 67: $811-816$

20. Somerville GA, Proctor RA (2009) At the crossroads of bacterial metabolism and virulence factor synthesis in staphylococci. Microbiol Mol Biol Rev 73: 233-248

21. Rutherford ST, Bassler BL (2012) Bacterial quorum sensing: its role in virulence and possibilities for its control. Cold Spring Harb Perspect Med 2: a012427

22. Wang X, Yue J, Ding C, Wang S, Liu B, Tian M, Yu S (2016) Deletion of AS87_03730 gene changed the bacterial virulence and gene expression of Riemerella anatipestifer. Sci Rep 6: 22438. doi:10.1038/ srep22438

23. Kim JK (2009) Disruption of genes related tolaasin biosynthesis by transposon mutagenesis of Pseudomonas tolaasii. Dissertation, Gyeongsang National University

24. Fakruddin M (2012) Biosurfactant: production and application. J Pet Environ Biotechnol 3: 124. doi: 10.4172/2157-7463.1000124

25. Wu YS, Ngai SC, Goh BH, Chan KG, Lee LH, Chuah LH (2017) Anticancer activities of surfactic and potential application of nanotechnology assisted surfactic delivery. Front Pharmocol 8: 761. doi: 10.3389/fphar2017.00761 